\title{
BIOCHEMICAL, HISTOCHEMICAL AND IMMUNO- CYTOCHEMICAL CHANGES IN THE ADRENAL CORTEX OF ADULT MALE DOMESTIC PIGEON, COLUMBA LIVIA IN RELATION TO ANNUAL TESTICULAR AND ENVIRONMENTAL CYCLES
}

\author{
Nithar Ranjan Madhu ${ }^{1 *}$, Bhanumati Sarkar ${ }^{2}$ and Chanchal Kumar Manna ${ }^{3}$ \\ ${ }^{1}$ Department of Zoology, Bajkul Milani Mahavidyalaya, Purba Medinipur-721655,West Bengal, India \\ ${ }^{2}$ Department of Biology, Ranaghat Vivekananda Balika Vidyalaya, Ranaghat-741201, Nadia, West \\ Bengal, India \\ ${ }^{3}$ Endocrinology Laboratory, Department of Zoology, University of Kalyani, Nadia, Kalyani-741235, West \\ Bengal, India \\ Accepted 20 December 2010
}

\begin{abstract}
The present study was conducted to investigate the seasonal physiological relationship between the gonad and adrenal gland of the adult male domestic pigeon, Columba livia. This study reports the seasonal activity cycle of the testes and adrenal gland in relation to lipids, ascorbic acid, alkaline and acid phosphatases and P450 side chain cleavage enzyme (SCC). The mean maximum daily temperature and minimum relative humidity were recorded in April, 2007 (primary breeding phase) during which both testicular and adrenal cholesterol and ascorbic acid levels were significantly low. Maximum relative humidity was lowest in December. The maximum total monthly rainfall was recorded in June and the minimum in December, January and February. Cholesterol and ascorbic acid levels in the testis and adrenal gland increased in June, July, August, December, January and February. Testicular and adrenal alkaline and acid phosphatase activity was found to be higher during the breeding period (March, April and May) and lowest in the non-breeding period (June, July and August). The accumulation of sudanophilic lipid materials was found to increase within the seminiferous tubules and decrease in both the sub-capsular (SCZ) and central zone (CZ) during the primary breeding phase. Sudanophilic lipids increased in the interstitium of testes, SCZ and CZ during regressive phase-I. High intensities of alkaline phosphatase activity were found to be localized within the interstitium and basement membrane during the breeding period. Acid phosphatase was also higher in the interstitium regions during the breeding period. The reactions of SCC enzymes were highly positive in the CZ than in the SCZ during the primary breeding phase.
\end{abstract}

Keywords: adrenal gland, acid phosphatase, alkaline phosphatase, gonadal, histochemistry, immunocytochemistry, primary breeding phase, regressive phase.

\section{INTRODUCTION}

The adrenal gland in birds appears to be influenced by the environment more than any other endocrine gland in the body. External environmental stimuli (photoperiod, sound, temperature), emotional or traumatic stress regulate the activity of the hypothalamo hypophysial-adrenal-axis (Wingfield et al., 1995). Temperature and traumatic stress also influence adrenal and pineal function (Astheimer et al., 1995). Under natural environmental conditions in different birds, seasonal activities of adrenocortical and gonadal tissues have been shown to be either parallel (Thapliyal, 1981), inverse (Silverin, 1979), or out of phase (Chaturvedi and Thapliyal, 1979). Several stressful environmental conditions such as reduced food availability, low ambient temperature, overcrowding, lack of shelter or increased number of predators can lead to seasonal fluctuation in immune function among individuals and seasonal changes in populationwide-diseases and death of vertebrates (Nelson, 2004). During summer days long photoperiod and higher gonadal steroids are responsible for reproductive activity which suppress the immune system in birds (Sing and Haldar, 2005; Weil et

$\overline{\text { *Corresponding author's email: nithar_1@yahoo.com }}$ 
$a l ., 2006)$. The variation in peripheral melatonin concentration by natural light conditions acts as a bolster to the immune function which suppresses the gonadal activity in winter and help the individuals to fight seasonal stresses (food scarcity and low ambient temperature) in the Indian male bird, Perdicula asiatica (Sing and Haldar, 2007).

Two peak periods of breeding (primary breeding phase in March, April and May and secondary breeding phase in September and October), rise in environmental temperature and moderate humidity contribute to rise in adrenalgonadal function and reduced pineal function (Madhu and Manna, 2009; Madhu and Manna, 2010). Therefore, the present study was undertaken to assess the physiological relationship, particularly the seasonal adrenocortical and gonadal cycle in the male domestic pigeon, Columba livia Gmelin in response to environmental factors.

\section{MATERIALS AND METHODS}

The study was conducted on obtaining permission from the Ethical Committee, Department of Zoology, University of Kalyani, Kalyani-741235, Nadia, West Bengal, India. Adult male domestic pigeons, Columba livia (220-260 g in weight) were collected periodically from the local bird supplier in Kalyani, W.B., India. The pigeons were collected on the first week of every month. After collection, all the birds were maintained under normal laboratory conditions, at least for seven days and provided with food (50 gm/day/ bird) and sufficient water. Every month at least fifteen birds were used in the investigation. After seven days, all the birds were weighed and sacrificed on the $2^{\text {nd }}$ and $4^{\text {th }}$ week of every month. Right testes and adrenal glands were removed immediately.

Adrenal tissues were fixed by immersion in pre-cooled $4 \%$ paraformaldehyde in phosphate buffer for 24 hours at $4^{0} \mathrm{C}$. They were processed and embedded in paraffin. Sections $6 \mu \mathrm{m}$ thick were cut and placed on gelatin coated microscope slides. They were incubated in polyclonal antiserum p-450 SCC, raised in rabbit (dilution $1: 500$ ) for 12 hours at $4^{0} \mathrm{C}$. Staining was detected using a vectastain biotinylated secondary antibody in combination with the avidian biotin peroxidase complex (ABC) (Vector Laboratory, CA, USA) with DAB (Sigma Chem. Co. Mo., USA) as a chromogen.
Testicular and adrenal tissues were processed for biochemical estimation of total cholesterol (Zarrow et al., 1964), ascorbic acid (Walter and Schutt, 1974), acid and alkaline phosphatases (Nino and Prasad, 1980). Histochemical studies were carried out on frozen sections for lipids (Sudan III \& IV) (Kay and Whitehead, 1941), acid phosphatase (Bitensky, 1963) and alkaline phosphatase (Butcher and Chayan, 1966).

The biochemical data were statistically analysed using correlation co-efficient and oneway ANOVA (Minitab version-13.1).

\section{RESULTS}

\section{Environmental Factors}

The maximum mean daily temperature recorded in April, 2007 was $36.49 \pm 0.37^{\circ} \mathrm{C}$ and the minimum was $23.70 \pm 0.44^{\circ} \mathrm{C}$. The minimum mean daily temperature was in January and the maximum in May. The maximum mean humidity was in November, December, January and February and the minimum in March, April, May and June. Maximum daily humidity in December was $99.71 \pm 0.21$ and the minimum in April was $92.03 \pm 0.69$. The relative humidity corresponded with the period of maximum temperature. Maximum total monthly rainfall was recorded in June and the minimum in December, January and February.

\section{Biochemical investigations}

The different biochemical components (cholesterol, alkaline phosphatase, acid phosphatase and ascorbic acid) in the testis and the adrenal gland of pigeons during the period January to December showed significant variations $(\mathrm{F}=205.95 ; 34.27$; 345.98; 3.92, $\mathrm{P}<$ 0.001 within the testis and $\mathrm{F}=139.93 ; 69.17$; $440.09 ; 777.87, \mathrm{P}<0.001$ within the adrenal gland).

Testicular and adrenal cholesterol and ascorbic acid levels were significantly reduced at the peak primary and secondary breeding phases. But in the non-breeding phase cholesterol and ascorbic acid levels in the testis and adrenal gland had reached the maximum level (Figs. $1 \&$ $3)$. In the month of February, cholesterol and ascorbic acid were at moderate level. Testicular and adrenal alkaline and acid phosphatases activity was higher during the primary and secondary breeding phases than in the nonbreeding phases (Figs. $2 \& 4$ ). 


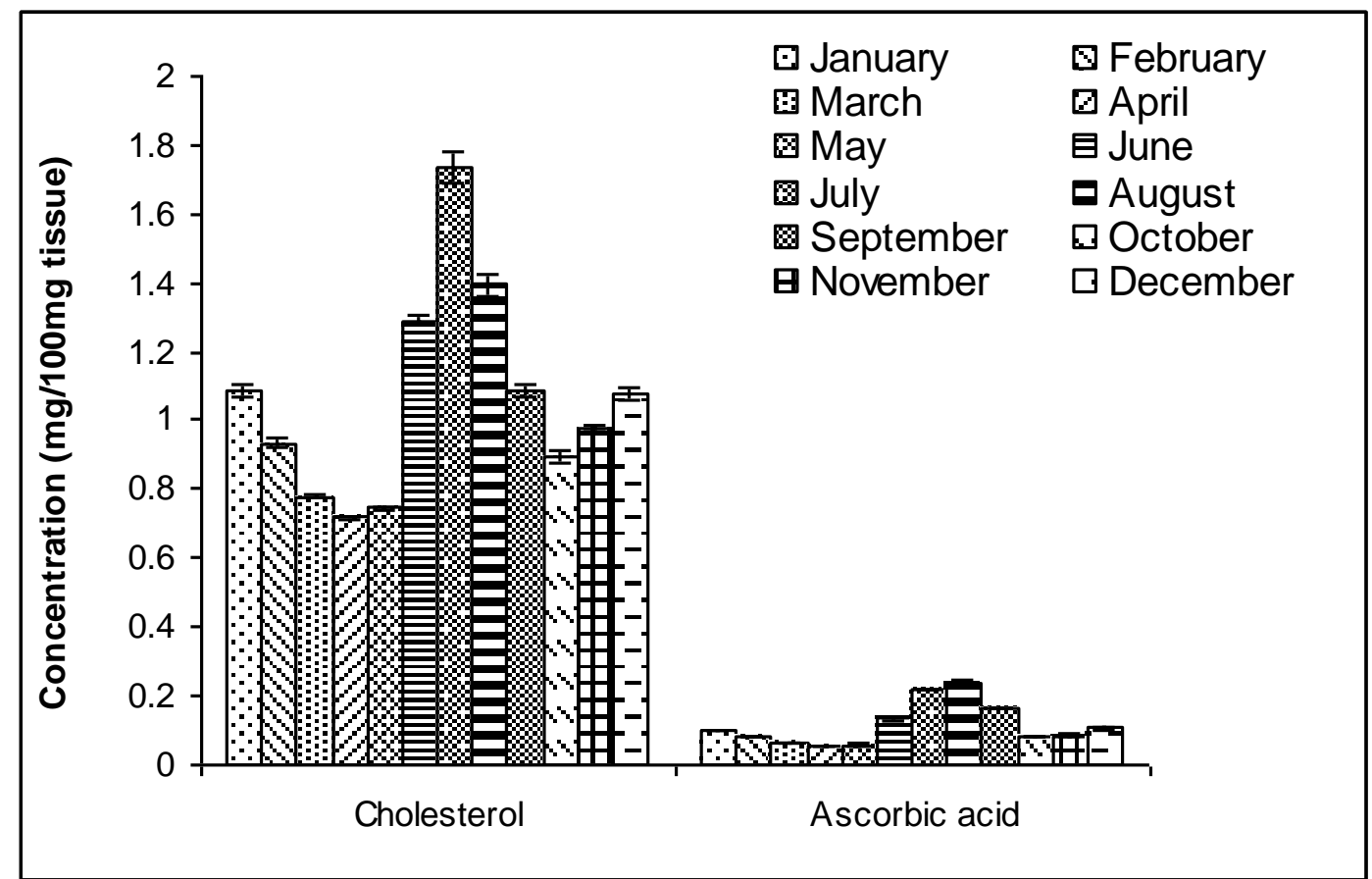

Figure 1. Seasonal changes in cholesterol and ascorbic acid levels in the testicular tissue of the adult male domestic pigeon, $C$. livia.

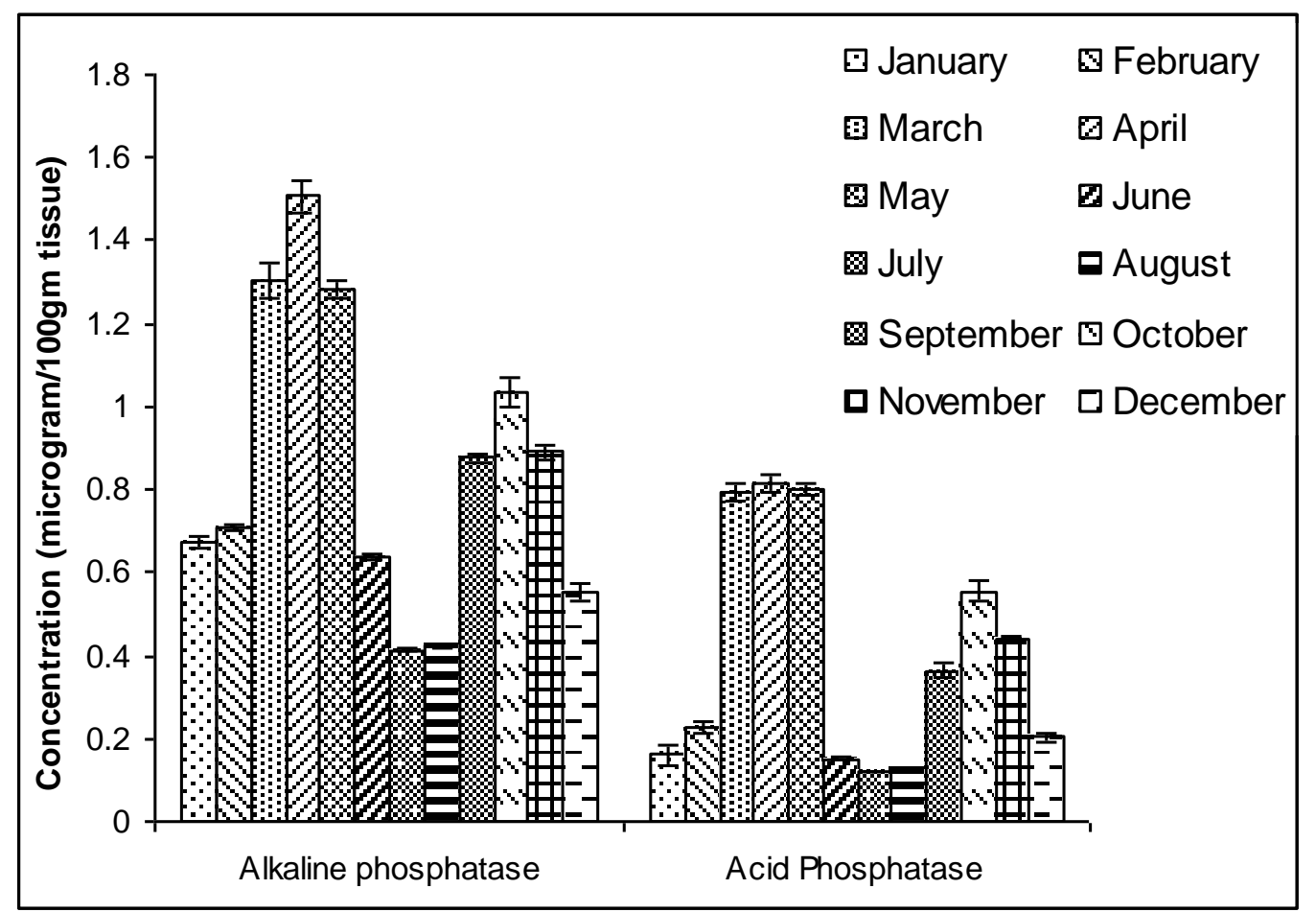

Figure 2. Seasonal changes in alkaline and acid phosphatases in the testicular tissue of the adult male domestic pigeon, C. livia. 


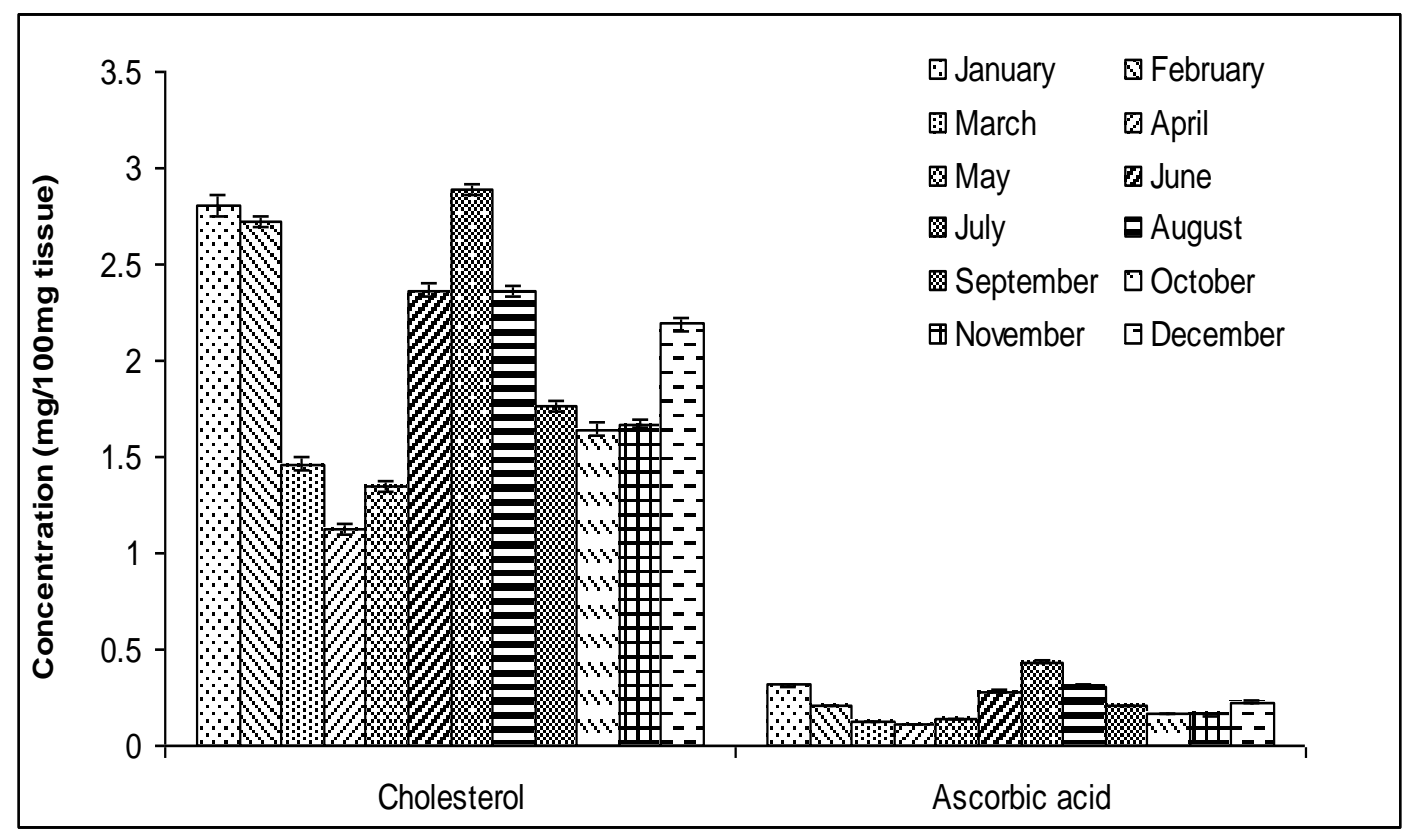

Figure 3. Seasonal changes in cholesterol and ascorbic acid in the adrenal tissue of the adult male domestic pigeon, $C$. livia.

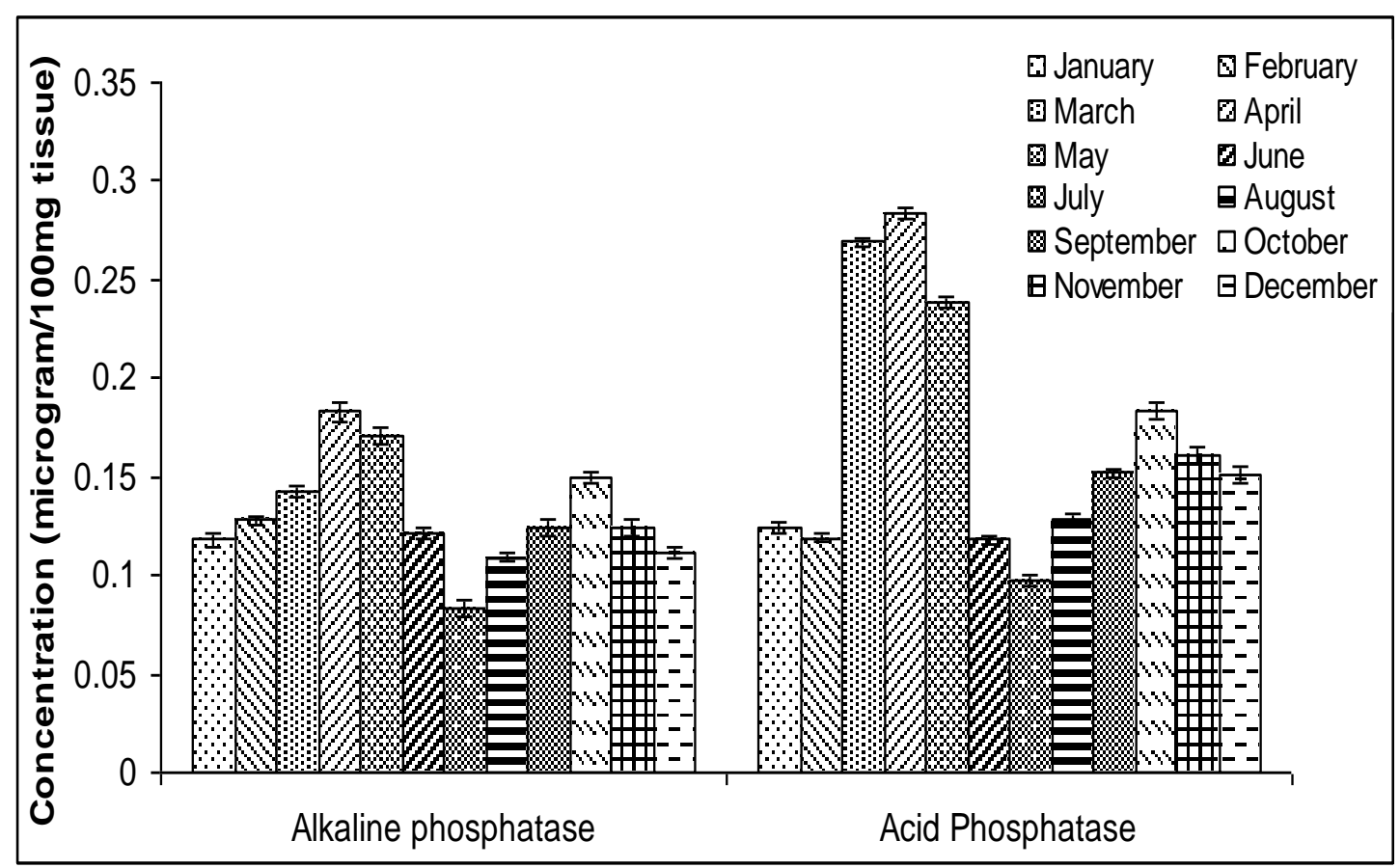

Figure 4. Seasonal changes in alkaline and acid phosphatases in the adrenal tissue of the adult male domestic pigeon, $C$. livia. 


\section{Histochemical investigations}

As the breeding season approached, sudanophilic lipids gradually decreased from the interstitium of the testis in both SCZ and CZ of the adrenal gland. In the testis, lipid granules were restricted to the seminiferous tubules and a very weak reaction was observed within the interstitium (Fig. 5a). Accumulations of lipid materials were found to be intense within the interstitium during the non-breeding phases (Table $1 \&$ Fig. 5b). The accumulation of lipids increased both in the SCZ and CZ regions of the adrenal gland during the non-breeding phases. There was no reaction in the medulla (Table 2).

The distribution of alkaline and acid phosphatases within the testicular and adrenal sections at different phases of the annual cycle exhibited significant variations. Intensity of reactions increased from the progressive phase (in February). Alkaline and acid phosphatase activity was high during primary and secondary breeding periods (Table 1). Strong activity was localized within the interstitium and basement membrane of the testis and the intensity in both SCZ and CZ regions were quite high in the primary and secondary breeding phases (Table 2). The intensity of reactions of acid phosphatases was found to be very high with the reacting sites showing a brownish grey colouration. The testicular and adrenal sections showed a gradual depletion in the distribution and concentration of alkaline and acid phosphatases during the non-breeding phases. The testis showed a very faint reaction and it was restricted to the region of spermatogonial cells.
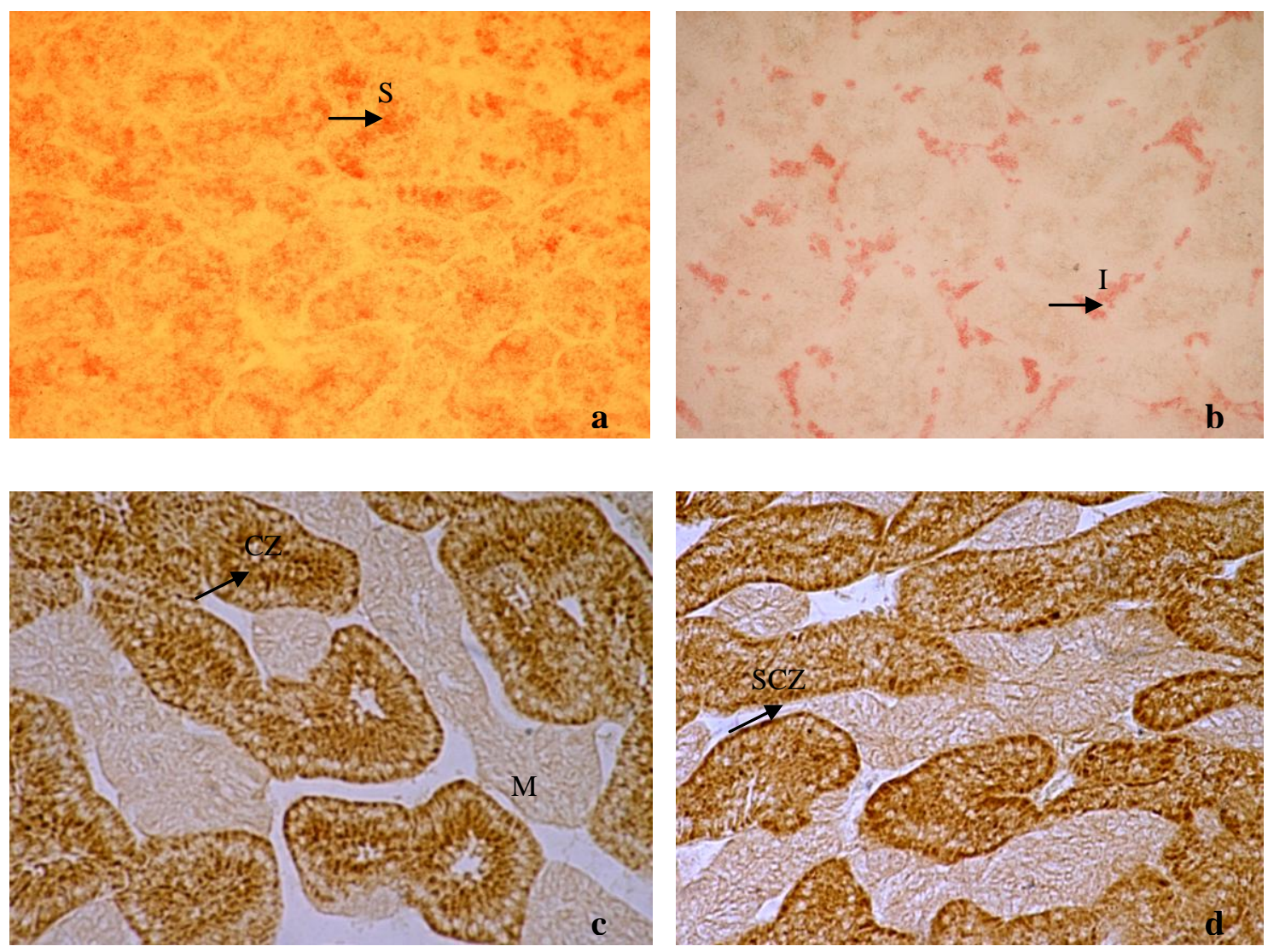

Figure 5. Cryocut section of testis during the breeding phase in pigeon showing (a) Accumulation of lipids within the seminiferous tubules (S) (200x); (b) High accumulations of sudanophilic lipids within the interstitium (I) of the testis in the regressive phase (200x); (c) High accumulation of SCC enzymes within the $\mathrm{CZ}$ region in the breeding phase (200x); (d) Very low accumulation of SCC enzymes in the $\mathrm{CZ}$ region and moderate accumulation in the $S C Z$ region of the adrenal gland in the regressive phase. Enzymes are absent in the medullary $(M)$ region $(200 x)$. 
Table 1. Seasonal histochemical changes within the testicular tissues of the adult male domestic pigeon, C. livia.

\begin{tabular}{|c|c|c|c|c|}
\hline Months & Regions & Lipids & $\begin{array}{c}\text { Alkaline } \\
\text { phosphatase }\end{array}$ & $\begin{array}{c}\text { Acid } \\
\text { phosphatase }\end{array}$ \\
\hline January & $\begin{array}{l}\text { i. Capsule ( C ) } \\
\text { ii. Basement membrane (B) } \\
\text { iii. Seminiferous tubules (ST) } \\
\text { iv. Interstitium (I) }\end{array}$ & $\begin{array}{l}- \\
+ \\
- \\
+\end{array}$ & $\begin{array}{c}+ \\
+ \\
++ \\
+\end{array}$ & $\begin{array}{c}+ \\
+ \\
++ \\
+\end{array}$ \\
\hline February & $\begin{array}{l}\text { i. Capsule ( C ) } \\
\text { ii. Basement membrane (B) } \\
\text { iii. Seminiferous tubules (ST) } \\
\text { iv. Interstitium (I) }\end{array}$ & $\begin{array}{l}- \\
+ \\
- \\
+\end{array}$ & $\begin{array}{l}- \\
+ \\
+ \\
+\end{array}$ & $\begin{array}{l}+ \\
+ \\
+ \\
+\end{array}$ \\
\hline March & $\begin{array}{l}\text { i. Capsule ( C ) } \\
\text { ii. Basement membrane (B) } \\
\text { iii. Seminiferous tubules (ST) } \\
\text { iv. Interstitium (I) }\end{array}$ & $\begin{array}{c}- \\
+ \\
+ \\
+ \\
-\end{array}$ & $\begin{array}{c} \pm \\
++ \\
+ \\
++\end{array}$ & $\begin{array}{l}+ \\
+ \\
+ \\
++\end{array}$ \\
\hline April & $\begin{array}{l}\text { i. Capsule ( C ) } \\
\text { ii. Basement membrane (B) } \\
\text { iii. Seminiferous tubules (ST) } \\
\text { iv. Interstitium (I) }\end{array}$ & $\begin{array}{c}- \\
- \\
++ \\
-\end{array}$ & $\begin{array}{c}+ \\
+ \\
++ \\
+ \\
++\end{array}$ & $\begin{array}{c}+ \\
++ \\
+ \\
+ \\
++\end{array}$ \\
\hline May & $\begin{array}{l}\text { i. Capsule ( C ) } \\
\text { ii. Basement membrane (B) } \\
\text { iii. Seminiferous tubules (ST) } \\
\text { iv. Interstitium (I) }\end{array}$ & $\begin{array}{c}- \\
- \\
++ \\
-\end{array}$ & $\begin{array}{c}+ \\
+++ \\
+ \\
++\end{array}$ & $\begin{array}{c}+ \\
++ \\
+ \\
++\end{array}$ \\
\hline June & $\begin{array}{l}\text { i. Capsule ( C ) } \\
\text { ii. Basement membrane (B) } \\
\text { iii. Seminiferous tubules (ST) } \\
\text { iv. Interstitium (I) }\end{array}$ & $\begin{array}{l}- \\
- \\
+ \\
+\end{array}$ & $\begin{array}{c}- \\
+ \\
+ \\
+ \\
-\end{array}$ & $\begin{array}{c}+ \\
+ \\
++ \\
+\end{array}$ \\
\hline July & $\begin{array}{l}\text { i. Capsule ( C ) } \\
\text { ii. Basement membrane (B) } \\
\text { iii. Seminiferous tubules (ST) } \\
\text { iv. Interstitium (I) }\end{array}$ & $\begin{array}{c}- \\
- \\
- \\
++\end{array}$ & $\begin{array}{c}- \\
++ \\
++ \\
-\end{array}$ & $\begin{array}{c}+ \\
\pm \\
++ \\
-\end{array}$ \\
\hline August & $\begin{array}{l}\text { i. Capsule (C) } \\
\text { ii. Basement membrane (B) } \\
\text { iii. Seminiferous tubules (ST) } \\
\text { iv. Interstitium (I) }\end{array}$ & $\begin{array}{c}- \\
- \\
+ \\
++\end{array}$ & $\begin{array}{c}- \\
+ \\
++ \\
-\end{array}$ & $\begin{array}{c}+ \\
- \\
++ \\
-\end{array}$ \\
\hline September & $\begin{array}{l}\text { i. Capsule ( C ) } \\
\text { ii. Basement membrane (B) } \\
\text { iii. Seminiferous tubules (ST) } \\
\text { iv. Interstitium (I) }\end{array}$ & $\begin{array}{c}- \\
- \\
++ \\
-\end{array}$ & $\begin{array}{c}+ \\
++ \\
++ \\
++\end{array}$ & $\begin{array}{l}- \\
+ \\
+ \\
++\end{array}$ \\
\hline October & $\begin{array}{l}\text { i. Capsule ( C ) } \\
\text { ii. Basement membrane (B) } \\
\text { iii. Seminiferous tubules (ST) } \\
\text { iv. Interstitium (I) }\end{array}$ & $\begin{array}{c}- \\
- \\
+++ \\
-\end{array}$ & $\begin{array}{c}+ \\
++ \\
+ \\
+ \\
++\end{array}$ & $\begin{array}{c}- \\
+ \\
+ \\
+ \\
++\end{array}$ \\
\hline November & $\begin{array}{l}\text { i. Capsule ( C ) } \\
\text { ii. Basement membrane (B) } \\
\text { iii. Seminiferous tubules (ST) } \\
\text { iv. Interstitium (I) }\end{array}$ & $\begin{array}{c}- \\
- \\
++ \\
-\end{array}$ & $\begin{array}{c}+ \\
++ \\
+ \\
+\end{array}$ & $\begin{array}{l}- \\
+ \\
+ \\
++\end{array}$ \\
\hline December & $\begin{array}{l}\text { i. Capsule ( C ) } \\
\text { ii. Basement membrane (B) } \\
\text { iii. Seminiferous tubules (ST) } \\
\text { iv. Interstitium (I) }\end{array}$ & $\begin{array}{l}- \\
+ \\
+ \\
+\end{array}$ & $\begin{array}{c}- \\
+ \\
++ \\
-\end{array}$ & $\begin{array}{c}+ \\
+ \\
++ \\
+\end{array}$ \\
\hline
\end{tabular}

- Negative ; \pm Insignificant $;+$ Positive $;++$ Moderately positive ; +++ Highly positive 
Table 2. Seasonal histochemical changes within the adrenal tissue of the adult male domestic pigeon, C. livia.

\begin{tabular}{|c|c|c|c|c|}
\hline Months & Regions & Lipids & $\begin{array}{l}\text { Alkaline } \\
\text { phosphatase }\end{array}$ & $\begin{array}{l}\text { Acid } \\
\text { phosphatase }\end{array}$ \\
\hline January & $\begin{array}{l}\text { i) Sub-capsular zone (SCZ) } \\
\text { ii) Central zone (CZ) } \\
\text { iii) Medulla }\end{array}$ & $\begin{array}{c}++ \\
++ \\
-\end{array}$ & $\begin{array}{l}+ \\
+ \\
-\end{array}$ & $\begin{array}{l}+ \\
+ \\
\pm\end{array}$ \\
\hline February & $\begin{array}{l}\text { i) Sub-capsular zone (SCZ) } \\
\text { ii) Central zone (CZ) } \\
\text { iii) Medulla }\end{array}$ & $\begin{array}{c}+ \\
++ \\
-\end{array}$ & $\begin{array}{c}++ \\
++ \\
-\end{array}$ & $\begin{array}{c}++ \\
++ \\
-\end{array}$ \\
\hline March & $\begin{array}{l}\text { i) Sub-capsular zone (SCZ) } \\
\text { ii) Central zone (CZ) } \\
\text { iii) Medulla }\end{array}$ & $\begin{array}{c}+ \\
++ \\
-\end{array}$ & $\begin{array}{c}+++ \\
++ \\
-\end{array}$ & $\begin{array}{c}++ \\
+++ \\
-\end{array}$ \\
\hline April & $\begin{array}{l}\text { i) Sub-capsular zone (SCZ) } \\
\text { ii) Central zone (CZ) } \\
\text { iii) Medulla }\end{array}$ & $\begin{array}{l}+ \\
+ \\
-\end{array}$ & $\begin{array}{c}++ \\
+++ \\
-\end{array}$ & $\begin{array}{c}++ \\
+++ \\
-\end{array}$ \\
\hline May & $\begin{array}{l}\text { i) Sub-capsular zone (SCZ) } \\
\text { ii) Centra zone (CZ) } \\
\text { iii) Medulla }\end{array}$ & $\begin{array}{c}+ \\
++ \\
-\end{array}$ & $\begin{array}{c}++ \\
+++ \\
-\end{array}$ & $\begin{array}{c}++ \\
+++ \\
-\end{array}$ \\
\hline June & $\begin{array}{l}\text { i) Sub-capsular zone (SCZ) } \\
\text { ii) Central zone (CZ) } \\
\text { iii) Medulla }\end{array}$ & $\begin{array}{c}++ \\
++ \\
-\end{array}$ & $\begin{array}{c}+ \\
++ \\
-\end{array}$ & $\begin{array}{c}+ \\
++ \\
-\end{array}$ \\
\hline July & $\begin{array}{l}\text { i) Sub-capsular zone (SCZ) } \\
\text { ii) Centra zone (CZ) } \\
\text { iii) Medulla }\end{array}$ & $\begin{array}{c}++ \\
+++ \\
-\end{array}$ & $\begin{array}{l}+ \\
+ \\
-\end{array}$ & $\begin{array}{c}+ \\
++ \\
-\end{array}$ \\
\hline August & $\begin{array}{l}\text { i) Sub-capsular zone (SCZ) } \\
\text { ii) Central zone (CZ) } \\
\text { iii) Medulla }\end{array}$ & $\begin{array}{c}++ \\
+++ \\
-\end{array}$ & $\begin{array}{l} \pm \\
+ \\
-\end{array}$ & $\begin{array}{l} \pm \\
+ \\
\pm\end{array}$ \\
\hline September & $\begin{array}{l}\text { i) Sub-capsular zone (SCZ) } \\
\text { ii) Central zone (CZ) } \\
\text { iii) Medulla }\end{array}$ & $\begin{array}{l}++ \\
++ \\
-\end{array}$ & $\begin{array}{c}++ \\
++ \\
-\end{array}$ & $\begin{array}{c}++ \\
++ \\
-\end{array}$ \\
\hline October & $\begin{array}{l}\text { i) Sub-capsular zone (SCZ) } \\
\text { ii) Central zone (CZ) } \\
\text { iii) Medulla }\end{array}$ & $\begin{array}{c}+ \\
++ \\
-\end{array}$ & $\begin{array}{c}+++ \\
++ \\
-\end{array}$ & $\begin{array}{c}++ \\
+++ \\
-\end{array}$ \\
\hline November & $\begin{array}{l}\text { i) Sub-capsular zone (SCZ) } \\
\text { ii) Central zone (CZ) } \\
\text { iii) Medulla }\end{array}$ & $\begin{array}{c}+ \\
++ \\
-\end{array}$ & $\begin{array}{l}++ \\
++ \\
-\end{array}$ & $\begin{array}{c}++ \\
+ \\
-\end{array}$ \\
\hline December & $\begin{array}{l}\text { i) Sub-capsular zone (SCZ) } \\
\text { ii) Central zone (CZ) } \\
\text { iii) Medulla }\end{array}$ & $\begin{array}{l}++ \\
++ \\
-\end{array}$ & $\begin{array}{l}+ \\
+ \\
-\end{array}$ & $\begin{array}{l} \pm \\
+ \\
-\end{array}$ \\
\hline
\end{tabular}

- Negative ; \pm Insignificant $;+$ Positive ; ++ Moderately positive ; +++ Highly positive 
Table 3. Seasonal changes in the immuno-cytochemical components (SCC enzymes) in the adrenal gland of the adult male domestic pigeon, $C$. livia.

\begin{tabular}{|c|c|c|c|c|}
\hline \multirow[t]{2}{*}{ Season } & \multirow[t]{2}{*}{ Method } & \multicolumn{2}{|c|}{ Cortex } & \multirow[t]{2}{*}{ Medulla } \\
\hline & & SCZ & $\mathbf{C Z}$ & \\
\hline Breeding phase & $\mathrm{SCC}$ & ++ & +++ & - \\
\hline $\begin{array}{l}\text { Non-breeding } \\
\text { phase }\end{array}$ & SCC & ++ & + & - \\
\hline
\end{tabular}

\section{Immno-cytochemistry}

A significant immuno-cytochemical reaction of side chain cleavage enzymes (SCC or CYP11A1) was observed within the adrenal gland.

SCC enzymes were highly positive in the CZ than in the SCZ during the primary and secondary breeding phases (Fig. 5c). But in the regressive phase-I and II, adreno-cortical regions showed low intensity of SCC enzymes within the $\mathrm{CZ}$ region and moderate intensities within the SCZ region (Fig. 5d). There was no reaction in the medullary tissues (Table 3 ).

\section{DISCUSSION}

Analyses of adrenal and testicular tissues in pigeon showed very intense activity of alkaline and acid phosphatases during the peak breeding period. At the same time the activity of adrenal and testicular cholesterol and ascorbic acid levels were very low. Sudanophilic lipids materials gradually decreased from the interstitium of the testis and the SCZ and $\mathrm{CZ}$ of the adrenal gland during the breeding phase.

Cholesterol is the precursor of androgens (Lofts and Murton, 1973). High accumulation of cholesterol and lipids within the interstitium during the non-breeding phases and low amount of cholesterol, low lipids materials during the breeding phase plays a vital role in steroidogenesis within the testicular tissue and adrenal gland in pigeon.

In the present study, SCC enzymes were highly positive in the $\mathrm{CZ}$ than in the SCZ, during the breeding phase. Exceptionally high levels of lipoprotein receptors in this highly vascularized tissue provide ready access to dietary cholesterol, allowing the adrenocortical cells to maintain impressive stores of cytoplasmic cholesterol (CE) ester droplets. Tightly packed among the CE droplets are specialized mitochondria, carrying high levels of the cytochrome P450 SCC (CYP11A1) enzyme in their inner membranes. This enzyme carries out the so-called side chain cleavage reaction, consuming cholesterol to produce pregnenolone, the precursor of cortisol and all other steroids. Glucocorticoid synthesis is tightly regulated at the level of cholesterol metabolism, which responds to ACTH stimulation over a period of minutes and ceases equally quickly when this hormone is removed. Remarkably, this dynamic process is modulated under most circumstances not by control of the intrinsic enzymatic activity of P450 SCC, but rather by substrate availability. The number of mitochondria and cytoplasmic secretory granules within both sub-capsular zone and central zone were found to be maximum during the primary breeding phase than in the regressive phase-I (Madhu and Manna, 2009). For this reason, cholesterol transport within the mitochondria has emerged as the key control point for steroidogenesis (Colin, 2002).

Ascorbic acid level was very low during the breeding phase and the highest level was recorded during the regressive phase. Role of ascorbic acid in the process of spermatogenesis is well-known (Shimizu, 1970). Noach and Van Rees (1958) also suggested that ascorbic acid may either be specifically involved in the production of corticoids or in the formation of steroid hormones from their precursors. In the present study, the high concentration of testicular ascorbate during the non-breeding season may exert a negative influence on steroid biosynthesis. It is also possible that stoppage of steroid biosynthesis results in cholesterol accumulation in both tissues. Further, ascorbic acid is known as a catalyst for both lipid peroxidation and alteration of unsaturated fatty acid composition (Shimzu, 1970). Lower levels of ascorbic acid during the breeding phase may be due to the active utilization of ascorbic acid in the process of steroidogenesis during these periods. Thus, this study highlights the finding that minimum cholesterol and ascorbic acid levels are present in the adrenal gland during the highest activity period of the gonads. 
Higher levels and intensities of alkaline and acid phosphatases were recorded during the breeding phase and the lowest in the regressive phase. Alkaline phosphatase is required for the synthesis of glycogen, which in turn appears to participate in the metabolic process of spermatogenesis (Sohval, 1958). It has been reported that the enzymes (acid and alkaline phosphatases) are mainly associated with growth, differentiation, and maturation of the spermatogenic elements of mammalian testis (Singer et al., 1980). These enzymes are also involved in removing cytoplasmic droplets of acrosomes in rat (Terner et al., 1975). In the present study, the strong activity of acid and alkaline phosphatase enzymes in the testis indicates the active participation of these enzymes in the process of spermatogenesis at the peak breeding periods. High levels of acid and alkaline phosphatase enzymes were also found within the adrenal gland.

Marshall (1970) points out that other than light there are more proximate synchronizers like rainfall, which can trigger reproduction. Although there is information on a variety of other stimuli, proximate synchronizers have been precisely defined other than rainfall and photoperiod (Lofts and Murton, 1967). Maximum total monthly rainfall was recorded in June and minimum in December, January and February. In this study, rainfall as an environmental factor reduced gonadal activity in the pigeon.

In conclusion, the present study showed parallel changes in adrenal and gonadal activity during the annual reproductive cycle. During early summer months, the long day-length, high temperature, relative humidity and relative rainfall increased towards maximum levels. Increased adrenal function, may aid in coping with possible emergency conditions such as mate guarding, territorial defense, nesting, feeding, and other potential demands during peak reproductive functions (Astheimer et al., 1995).

The changes in cholesterol, alkaline and acid phosphatase and ascorbic acid concentrations in the gonadal and adrenal tissues during the breeding cycle in the pigeon conclusively prove their variation during the annual reproductive cycle. Furthermore, histochemical studies of the testicular tissues and adrenal gland and immunohistochemical study of the SCC enzymes in the adrenal gland show similar significant results. Peak adrenal activity coincided with peak gonadal activity, suggesting a probable involvement of environmental stimuli with adrenal function.

\section{ACKNOWLEDGEMENTS}

Financial assistance from the University of Kalyani (IF-1/2001/DP-993), Kalyani-741235, Nadia, West Bengal, India is gratefully acknowledged.

\section{REFERENCES}

Assenmacher, I. (1973). The peripheral endocrine glands. In; Farner, D. S. and King, J. R. (eds). Avian Biology. Academic Press, New York. Vol. III, Pp. 183-286.

Astheimer, L. B., Buttemes, W. A. and Wingfield, J. C. (1995). Seasonal and acute changes in adrenocortical responsiveness in an arctic-breeding bird. Horm. Behav. 29: 442-457.

Bitensky, L. (1963). Modifications of the Gomori acid phosphatase technique for controlled temperature frozen sections. Quart. J. Micros. Sci. 104: 193-196.

Butcher, R. G. and Chayan, J. (1966). Quantitative studies on the alkaline phosphatase reaction. J. Roy. Micros. Soc. 85: 111-117.

Chaturvedi, C. M. and Thapliyal, J. P. (1979). Comparative study of adrenal cycles in three species of the Indian birds (Athena brama, Acridotheres tristis and Coturnix coturnix). Ind. J. Expt. Biol. 17: 1049-1052.

Collin, J. P. (2002). High-flux mitochondrial cholesterol trafficking, a specialized function of the adrenal cortex. J. Clin. Invest. 110: 881-890.

Kay, W. W. and Whitehead, R. (1941). Sudan III and IV methods for neutral fats. In: Pearse, A. G. E. (ed). Histochemistry-Theoretical and Applied $2^{\text {nd }}$ eds. Pp. 853-854.

Lofts, B. and Murton, R. K. (1967). The effects of cadmium on the avian testes. J. Reprod. Fert. 13: $155-164$.

Lofts, B. and Murton, R. K. (1973). Reproduction in birds. In: Farner, D. S. and King, J. R. (eds). Avian biology. Vol. III. Academic Press, London and New York. Pp. 1107. 
Madhu, N. R. and Manna, C. K. (2010). Pinealadrenal interactions in domestic male pigeon exposed to variable circadian light regimes and exogenous melatonin. Endocrine Regulation 44: 121-127

Madhu, N. R. and Manna, C. K. (2009). Seasonal histophysiological study of the pineal gland in relation to gonadal and adrenal gland activities in adult domestic pigeon, Columba livia Gmelin. Proc. Zoo. Soc. 62 (1): 13-22.

Marshall, A. J. (1970). Environmental factors other than light involved in the control of sexual cycles in birds and mammals. In: Benoit, J. and Assenmacher, I. (eds). La photoregulation de la reproduction chez les Oiseaux et les Mammiferes. '. Paris: Colloq. Intern. C. R. S. Pp. 53-70.

Nelson, R. J. (2004). Seasonal immune function and sickness responses. Trends Immunol. 25: 187-191.

Nino, H. V. and Prasad, A. S. (1980). Ascorbic acid (Vitamin C). In: Sonnenwirth, A. C. and Jarett, L. (eds) Vitamins and trace elements'. Gradwohl's Clinical Laboratory Methods and Diagnosis.. The C. V. Mosby Comp., St. Louis, Toronto, London. Vol. I. Pp. 370-372

Noach, E. L. and Van Rees, G. P. (1958). Ascorbic acid in the gonads of rat. Acta endocrinol. 27: 502-508.

Shimizu, K. (1970). Effects of ascorbic acid on the side chain cleavage of cholesterol. Biochem. Biophys. Acta. 210: 333-340.

Silverin, B. (1979). Activity of the adrenal glands in the pied flycatcher and its relation to testicular regression. Gen.Comp. Endocrinol. 38: 162-171.

Sing. S. S. and Haldar, C. (2005). Melatonin prevents testosterone-induced suppression of immune parameters and splenocyte proliferation in Indian tropical jungle bush quail (Perdicula asiatica). Gen. Comp. Endocrinol. 141: 226232.

Sing, S. S. and Haldar, C. (2007). Peripheral melatonin modulates seasonal immunity and reproduction of Indian tropical male bird (Perdicula asiatica). Comp.Biochem. Physiol. 146: 446-450.
Singer, R., Barnet, M., Allalouf, U., Schwartzman, S., Sagiv, M., Landau, B., Segenreich, E. and Servadio, C. (1980). Some properties of acid and alkaline phosphatase in seminal fluid and isolated sperm. Arch. Androl. 5: 195-199.

Sohval, A. R. (1958). The anatomy and endocrine physiology of the male reproductive system. In: Velardo, J. T. (ed). The Endocrinology of Reproduction. Oxford University Press, New York. Pp. 243-312.

Terner, C., Mac Laughlin, J. and Smith, B. R. (1975). Changes in lipase and phosphatase activities of rat spermatozoa in transit from caput to cauda epididymis. J. Reprod. Fert. 45: 1-8.

Thapliyal, J. P. (1981). Endocrinology of avian reproduction. Presidential address. Proc. $68^{\text {th }}$ session of the Indian Sci. Cong. Association., Part II. 1-30.

Walter, K. and Schutt, C. (1974). Acid and alkaline phosphatase in serum (Two point method). In: Bergmeyer, H. U. (ed). Methods of Enzymatic Analysis. Academic Press, New York, Sanfrancisco, London. Vol. II. Pp. 856-860.

Weil, J.M., Martin, L. B., Workman, J. L. and Nelson, R. J. (2006). Immune challenges retards seasonal reproductive regression in rodents: evidence for terminal investment. Biol. Lett. 2: 293-396.

Wingfield, J. C., Reilly, K. M. and Astheimer, L. B. (1995). Ecological bases of the modulation of adrenocortical responses to stress in Arctic birds. Am. Zool. 35: 285-294.

Zarrow, M.X., Yochim, J.M. and Mc Carthy, J.L. (1964). Experimental endocrinology: A source book of basic techniques. Academic Press, New York. 